\title{
A COMPARISON OF THE CDIO AND EUR-ACE QUALITY ASSURANCE SYSTEMS
}

\author{
Johan Malmqvist \\ Chalmers University of Technology, Göteborg, Sweden
}

\begin{abstract}
In a CDIO programme, the CDIO syllabus, standards, and self-evaluation model constitute the core components of the programme's quality assurance system.

At the same time, CDIO programmes are also evaluated by national standards. A CDIO programme needs a quality assurance system which also fulfils these national requirements, and that is able to produce the evidence and documentation needed for a national evaluation with minimal additional effort. Efficient execution of this task requires understanding of the similarities and differences between the $\mathrm{CDIO}$ and national quality assurance systems.
\end{abstract}

In this paper, we consider the emerging European standards for accreditation of engineering programmes, the EUR-ACE standards. We account for a comparison between the CDIO syllabus and the EUR-ACE counterpart, the programme outcomes, and by the CDIO standards and EUR-ACE accreditation criteria, identifying similarities and differences. A discussion is conducted on the pros and cons of a rating scale-based system for continuous improvement and a threshold-based accreditation model.

The paper concludes that:

- The CDIO syllabus reflects a more encompassing view of engineering than EUR-ACE's, by considering the full product/system/process lifecycle, including the implementing and operating life phases. The proficiency levels of the CDIO and EUR-ACE are, however, difficult to compare.

- The EUR-ACE accreditation requirements are extensive and include elements not addressed in the CDIO framework, eg concerning financial resources and decisionmaking. The CDIO standards provide "solutions" on how to work with about $3 / 4$ of the issues raised in a EUR-ACE accreditation.

- Four of the CDIO standards (4, 5, 7, and 8) define educational elements which are not explicitly discussed in EUR-ACE accreditation requirements.

- An evaluation process based on a rating scale, such as the CDIO self-evaluation model, is more useful for continuous improvement than a threshold value scale, such as used in a EUR-ACE accreditation.

\section{KEYWORDS}

Quality assurance, CDIO, EUR-ACE, Engineering education 


\section{INTRODUCTION}

CDIO, in a general sense, aims to raise the quality of the educational programs that apply the concept. CDIO includes a number of components that can be classified as quality assurance tools: In a CDIO programme, the CDIO syllabus, standards, and self-evaluation model constitute the core components of the programme's quality assurance (QA) system.

At the same time, CDIO programmes are also evaluated by national standards, for example in accreditations such as the US ABET [1] system, or in evaluations such as conducted by the Swedish National Agency for Higher Education [2]. A CDIO programme needs a quality assurance system which also fulfils these national requirements, and that is able to produce the evidence and documentation needed for a national accreditation/evaluation with minimal additional effort. Efficient execution of this task requires understanding of the similarities and differences between the $\mathrm{CDIO}$ and national quality assurance systems.

Earlier work has compared the CDIO syllabus with the ABET criteria, the UK-SPEC criteria [3], and the Swedish engineering degree requirements [4]. A common finding is that the CDIO syllabus states more encompassing and detailed learning outcomes for engineering education. The CDIO standards and the associated self-evaluation model have been used as part of a Swedish national evaluation of engineering degree programmes, demonstrating that they can be applied for systematic comparisons of key issues across a large number of programmes $[5,6]$.

The mentioned quality standards are all national. In this paper, we are considering an international quality assurance framework standard, namely the emerging European framework standards for accreditation of engineering programmes, the EUR-ACE standards [7]. These standards have been developed as a part of the Bologna process, and can be expected to be of growing importance in the future, at least in the European context. We are also investigating the documentation required for accreditation with that produced by a CDIO quality assurance system, and discuss the principal differences between accreditation-based quality assurance system and rating scale-based quality assurance systems.

The objectives of this paper are to:

- Clarify the similarities and differences between a CDIO and a EUR-ACE-based quality assurance system.

- Identify the strengths and weaknesses of each model.

- Identify future development routes for both the CDIO and EUR-ACE quality assurance systems.

The results will inform CDIO programmes on how to relate to EUR-ACE and on how to plan for an accreditation.

The remainder of the paper is structured as follows. In the next section we review the CDIO quality assurance system, focusing on the CDIO syllabus, standards and associated selfevaluation model. A similar review is then presented for the EUR-ACE framework. This is followed by a comparison and discussion. Finally, conclusions are listed.

\section{THE CDIO QUALITY ASSURANCE SYSTEM}

Improving educational quality is a fundamental goal for CDIO. CDIO standard five states that a CDIO programme should have a system that evaluates the programme against the CDIO standards, and provides feedback to students, faculty, and other stakeholders for the purposes of continuous improvement [3]. 
Table 1

CDIO syllabus at second level of detail [3].

1 Technical Knowledge and Reasoning

1.1 Knowledge of underlying science

1.2 Core engineering fundamental knowledge

1.3 Advanced engineering fundamental knowledge

2 Personal and Professional Skills and Attributes

$\begin{array}{ll}2.1 & \begin{array}{l}\text { Engineering reasoning and problem } \\ \text { solving }\end{array} \\ 2.2 & \begin{array}{l}\text { Experimentation and knowledge } \\ \text { discovery }\end{array} \\ 2.4 & \text { System thinking } \\ 2.5 & \text { Personal skills and attributes } \\ 2.6 & \text { Professional skills and attributess }\end{array}$

3 Interpersonal Skills and Attributes: Teamwork and Communication

3.1 Multi-disciplinary teamwork

3.2 Communications

3.3 Communications in foreign languages

4 Conceiving, Designing, Implementing and Operating Systems in the Enterprise and Societal Context

4.1 External and societal context

4.2 Enterprise and business context

4.3 Conceiving and engineering systems

4.4 Designing

4.5 Implementing

4.6 Operating

The standard further suggests that multiple methods should be used to evaluate the programme, including course evaluations, instructor reflections, entry and exit interviews, reports of external reviewers, and follow-up studies with graduates and employers. However, three components can be said to constitute the core of the quality assurance system of a CDIO programme:

- The use of CDIO syllabus to define the programme's goals, ie WHAT the programme aims to achieve.

- The use of the CDIO standards as a guideline when designing and operating the programme, ie HOW the programme goals are achieved.

- The use of the CDIO self-evaluation to measure the programme's progress towards fulfilling the CDIO standards, ie HOW WELL is the programme performing.

\section{The CDIO Syllabus}

The CDIO syllabus is a comprehensive list of engineering education learning outcomes. It was developed through a systematic process including comparison with reference models such as the ABET criteria, peer reviews, workshops and surveys [6]. It serves as a basis for developing a programme goal statement. It is intentionally limited to non-discipline-specific learning outcomes such as experimentation, communication and designing. The programme itself must complement these with discipline-specific subject matter learning outcomes, for example in thermodynamics. Moreover, the CDIO syllabus only lists topics. It is up to the programme, in consultation with its stakeholders, to establish suitable levels of proficiency for each of the topics in order to develop proper learning outcomes. Table 1 shows the CDIO syllabus at the second level of detail. The complete syllabus is very comprehensive and detailed, with 3-4 additional levels and in total lists more than 400 topics.

\section{The CDIO Standards}

In order to meet the goals stated by the help of the CDIO syllabus, the design of a CDIO programme is guided by the CDIO standards, a set of twelve principles that characterizes this educational model as well as general good practice in education [3]. The CDIO standards were developed in response to the request from programme stakeholders to be able to recognize CDIO programs and their graduates. The standards serve as guidelines for educational program reform and evaluation, create benchmarks and goals with worldwide 
Table 2

The CDIO Standards [3]

\begin{tabular}{|c|c|c|c|}
\hline \multicolumn{4}{|c|}{ CDIO STANDARD } \\
\hline \multirow[t]{2}{*}{1} & CDIO as Context & \multirow[t]{2}{*}{7} & Integrated Learning Experiences \\
\hline & $\begin{array}{l}\text { Adoption of the principle that product, process, and } \\
\text { system lifecycle development and } \\
\text { deployment-Conceiving-Designing-Implementing- } \\
\text { Operating-are the context for engineering education. }\end{array}$ & & $\begin{array}{l}\text { Integrated learning experiences that lead to the acquisition } \\
\text { of disciplinary know ledge, as w ell as personal and } \\
\text { interpersonal skills; and product, process, and system } \\
\text { building skills. }\end{array}$ \\
\hline \multirow[t]{2}{*}{2} & CDIO Syllabus Outcomes & 8 & Active Learning \\
\hline & $\begin{array}{l}\text { Specific, detailed learning outcomes for personal and } \\
\text { interpersonal skills; and product, process, and system- } \\
\text { building skills, consistent w ith program goals and } \\
\text { validated by program stakeholders. }\end{array}$ & & $\begin{array}{l}\text { Teaching and learning based on active and experiential } \\
\text { learning methods. }\end{array}$ \\
\hline \multirow[t]{2}{*}{3} & Integrated Curriculum & 9 & Enhancement of Faculty CDIO Skills \\
\hline & $\begin{array}{l}\text { A curriculum designed w ith mutually supporting } \\
\text { disciplinary subjects, w ith an explicit plan to integrate } \\
\text { personal and interpersonal skills; and product, process, } \\
\text { and system building skills. }\end{array}$ & & $\begin{array}{l}\text { Actions that enhance faculty competence in personal and } \\
\text { interpersonal skills; and product, process, and system } \\
\text { building skills. }\end{array}$ \\
\hline \multirow[t]{2}{*}{4} & Introduction to Engineering & 10 & Enhancement of Faculty Teaching Skills \\
\hline & $\begin{array}{l}\text { An introductory course that provides the framew ork for } \\
\text { engineering practice in product, process, and system } \\
\text { building, and introduces essential personal and } \\
\text { interpersonal skills. }\end{array}$ & & $\begin{array}{l}\text { Actions that enhance faculty competence in providing } \\
\text { integrated learning experiences, in using active } \\
\text { experiential learning methods, and in assessment. }\end{array}$ \\
\hline \multirow[t]{2}{*}{5} & Design-Implement Experiences & 11 & CDIO Skills Assessment \\
\hline & $\begin{array}{l}\text { A curriculum that includes tw o or more design-implement } \\
\text { experiences, including one at a basic level and one at an } \\
\text { advanced level. }\end{array}$ & & $\begin{array}{l}\text { Assessment of student learning in personal and } \\
\text { interpersonal skills; and product, process, and system } \\
\text { building skills, as w ell as in disciplinary know ledge. }\end{array}$ \\
\hline \multirow[t]{2}{*}{6} & CDIO Workspaces & 12 & CDIO Program Evaluation \\
\hline & $\begin{array}{l}\text { Workspaces and laboratories that support and encourage } \\
\text { hands-on learning of product, process, and system } \\
\text { building, as w ell as disciplinary know ledge and social } \\
\text { learning. }\end{array}$ & & $\begin{array}{l}\text { A system that evaluates programs against these } \\
\text { standards, and provides feedback to students, faculty, } \\
\text { and other stakeholders for the purposes of continuous } \\
\text { improvement. }\end{array}$ \\
\hline
\end{tabular}

application, and provide a framework for continuous improvement. The standards address program philosophy, curriculum development, design-build experiences and workspaces, new methods of teaching and learning, faculty development, and assessment and evaluation. Table 2 lists the CDIO standards.

\section{The CDIO self-evaluation model}

The determination of a program's progress towards fulfilment of the CDIO standards is accomplished through self-evaluation. The fulfilment of each standard is measured by a fivelevel scale, which is used to rate the progress towards the planning, implementation and adoption of each CDIO standard. The rubrics of the five-level scale are stated in Figure 1 (left). The scale ranges from "initial program-level plan or pilot implementation" to "complete and adopted program-level and comprehensive implementation of the plan at the course or program levels, with continuous improvement processes in place", and thus provide a stepby-step guide for programme evolution. Self-evaluation using the $12 \mathrm{CDIO}$ standards and the five-level rating scale provides a tool for the monitoring of improvements via a series of evaluations where overall program improvement can be made visualized. See Figure 1.

The CDIO quality assurance components can then be included in a CDIO programme's quality assurance system, which should also include other components, such as course evaluation tools and student achievement follow-ups. As an example, Figure 2 shows the quality assurance system of Chalmers University of Technology's Mechanical engineering programme [9]. The quality assurance system is organized around a plan-do-check-act cycle with the CDIO components in relevant phases. 


\begin{tabular}{|l|l|}
\hline 0 & $\begin{array}{l}\text { No initial program-level plan or pilot } \\
\text { implementation }\end{array}$ \\
\hline 1 & $\begin{array}{l}\text { Initial program-level plan and pilot } \\
\text { implementation at the course or program } \\
\text { levels }\end{array}$ \\
\hline 2 & $\begin{array}{l}\text { Well-developed program-level plan and } \\
\text { prototype implementation at the course } \\
\text { or program levels }\end{array}$ \\
\hline 3 & $\begin{array}{l}\text { Complete and adopted program-level } \\
\text { implementation of the plan at the course } \\
\text { or program level under way }\end{array}$ \\
\hline 4 & $\begin{array}{l}\text { Complete and adopted program-level } \\
\text { and comprehensive implementation of } \\
\text { the plan at the course or program levels, } \\
\text { with continuous improvement processes } \\
\text { in place }\end{array}$ \\
\hline
\end{tabular}

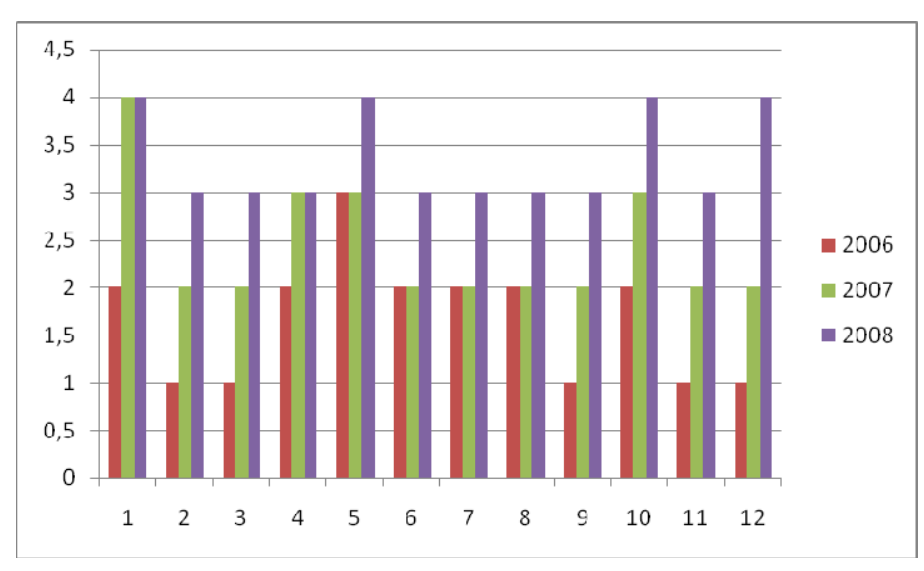

Figure 1. CDIO standards self-evaluation rating scale and chart showing improvement during a three-year period.

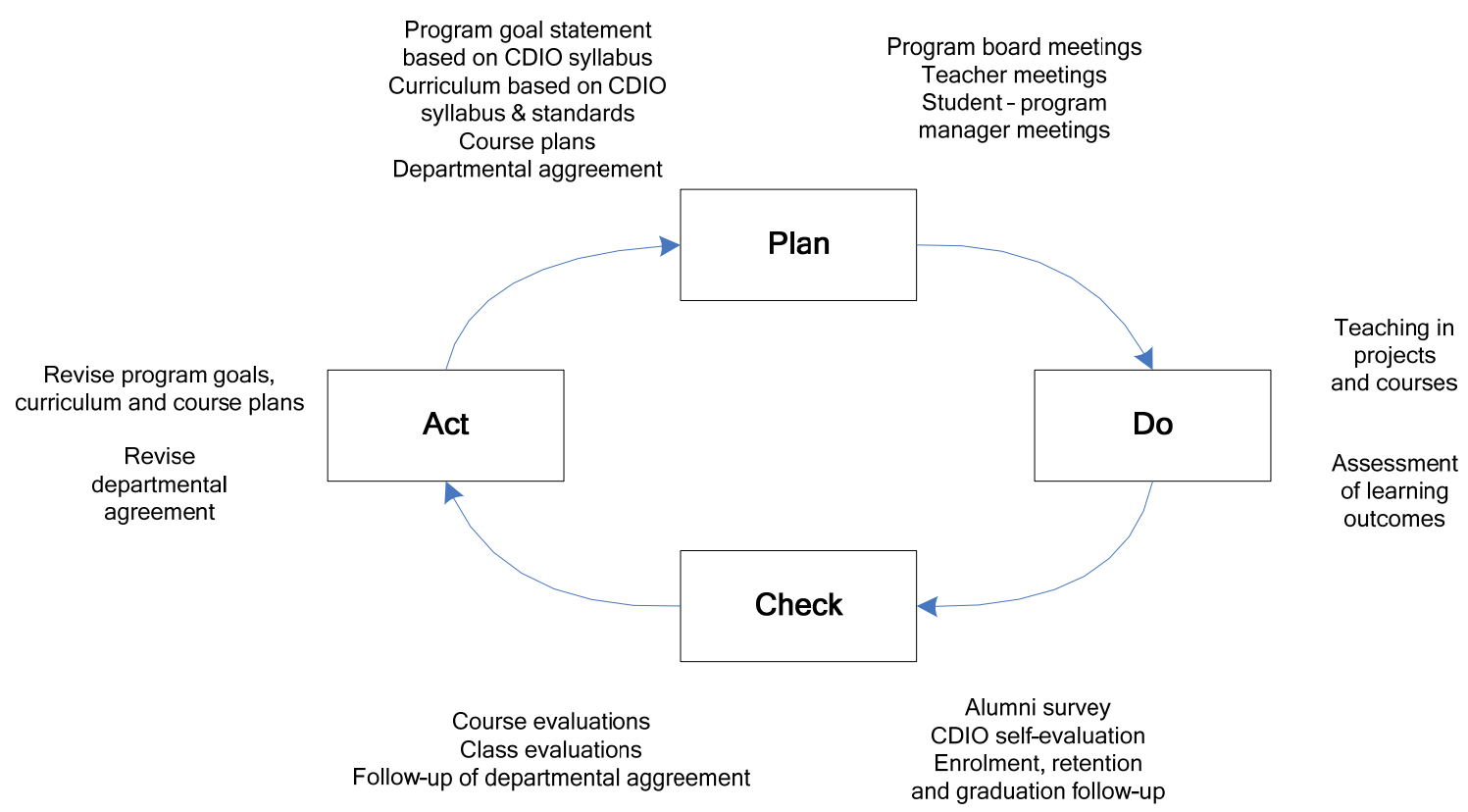

Figure 2. Example of quality loop in CDIO programme. Adapted from [9]. 


\section{THE EUR-ACE QUALITY ASSURANCE SYSTEM}

The Bologna process has in the European Higher Education Area (EHEA) resulted in a common qualifications framework comprising the $1^{\text {st }}$ (bachelor), $2^{\text {nd }}$ (master) and $3^{\text {rd }}$ (doctor) degree cycles. Components of the framework include the EQF qualifications [10] and the ECTS credit system. European standards for internal and external quality assurance are proposed [11].

The EQF qualifications framework relies on stated learning outcomes that are rather general and applicable across all university education sectors. In order to effectively guide education design and accreditation processes for specific fields, more detailed learning outcomes need to be defined. As a result, "sectoral EQFs" are emerging. The sectoral EQFs have the aim of developing the high-level EQF characteristics into detailed learning outcomes that should characterize specific professional degrees. In the field of engineering, the EUR-ACE framework standards [7] are taking this role.

The EUR-ACE standards comprise three main parts:

- A set of programme outcomes for $1^{\text {st }}$ and $2^{\text {nd }}$ cycle engineering degrees.

- Guidelines for programme assessment and accreditation.

- A procedure for programme assessment and accreditation.

\section{The EUR-ACE programme outcomes}

The EUR-ACE programme outcomes describe the capabilities required of graduates from $1^{\text {st }}$ and $2^{\text {nd }}$ cycle engineering degree programmes. They can thus be viewed as the "syllabus" of the EUR-ACE. We will use the term the EUR-ACE syllabus in the following. The EUR-ACE syllabus is structured in six main categories: Knowledge and understanding, Engineering analysis, Engineering design, Investigations, Engineering practice and Transferable skills.

The EUR-ACE syllabus for $1^{\text {st }}$ cycle degrees is shown in Table 3 . The $2^{\text {nd }}$ cycle version both adds progression with respect to the $1^{\text {st }}$ cycle outcomes, and adds some additional outcomes, for example "Work and communicate effectively in national and international contexts". The outcomes are not numbered in the original document; we have done so here in order to facilitate the comparison presented in the next section.

\section{EUR-ACE guidelines for programme assessment}

The second part of the EUR-ACE standards is the guidelines for programme assessment and accreditation. It is stated that a programme that seeks accreditation should have in place:

- Programme educational objectives consistent with the mission of the Higher Education Institution and the needs of all interested parties (such as students, industry, engineering associations, etc.) and programme outcomes consistent with the programme educational objectives and the programme outcomes for accreditation.

- A curriculum and related processes which ensure achievement of the programme outcomes.

- Academic and support staff, facilities, financial resources etc adequate to accomplish the programme outcomes.

- Appropriate forms of assessment which attest the achievement of the programme outcomes.

- A management system able to ensure the systematic achievement of the programme outcomes and the continual improvement of the programme. 
Table 3

EUR-ACE programme outcomes - the "EUR-ACE syllabus".

$1 \quad$ Knowledge and Understanding

1.1 Knowledge and understanding of the scientific and mathematical principles underlying their branch of engineering

1.2 A systematic understanding of the key aspects and concepts of their branch of engineering

1.3 Coherent knowledge of their branch of engineering including some at the forefront of the branch

2 Engineering Analysis

2.1 The ability to apply their knowledge and understanding to identify, formulate and solve engineering problems using established methods

2.2 The ability to apply their knowledge and understanding to analyse engineering products, processes and methods

2.3 The ability to select and apply relevant analytic and modelling methods

3 Engineering Design

3.1 The ability to apply their knowledge and understanding to develop and realise designs to meet defined and specified requirements

3.2 An understanding of design methodologies, and an ability to use them

4 Investigations

4.1 The ability to conduct searches of literature, and to use data bases and other sources of information

4.2 The ability to design and conduct appropriate experiments, interpret the data and draw

4.3 Workshop and laboratory skills

5 Engineering Practice

5.1 The ability to select and use appropriate equipment, tools and methods

5.2 The ability to combine theory and practice to solve engineering problems

5.3 An understanding of applicable techniques and methods, and of their limitations

5.4 An awareness of the non-technical implications of engineering practice

6 Transferable skills

6.1 Function effectively as an individual and as a member of a team

6.2 Use diverse methods to communicate effectively with the engineering community and with society at large

6.3 Demonstrate awareness of the health, safety and legal issues and responsibilities of engineering practice, the impact of engineering solutions in a societal and environmental context, and commit to professional ethics, responsibilities and norms of engineering practice

6.4 Demonstrate an awareness of project management and business practices, such as risk and change management, and understand their limitations

6.5 Recognise the need for, and have the ability to engage in independent, life-long learning

Accordingly, the guidelines for assessment and accreditation are divided into five main sections: Needs, objectives and outcomes, Educational process, Resources and partnerships, Assessment of the educational process and Management system. For each of these sections, criteria, requirements and related evidence that should be included in the accreditation documentation are identified.

Table 4 shows the main guideline sections, criteria and requirements. The lists of evidence required for accreditation numbers circa 30 items, including needs identified for all stakeholder [1.1], curriculum [2.1] and number and competence of staff [3.1]. Due to spatial constraints, the full list of evidence is not included here. However, it can be argued that the documentation required for accreditation is comprehensive. 
Table 4

EUR-ACE accreditation guideline sections, criteria and requirements.

\begin{tabular}{|c|c|c|}
\hline $\begin{array}{l}\text { Guidelines for } \\
\text { Accreditation }\end{array}$ & Criteria to be assessed & Requirements \\
\hline \multirow[t]{4}{*}{$\begin{array}{l}\text { 1. Needs, Objectives } \\
\text { and Outcomes }\end{array}$} & $\begin{array}{l}\text { 1.1 Needs of the } \\
\text { Interested Parties }\end{array}$ & $\begin{array}{l}\text { Have the needs of the interested parties (such as students, industry, } \\
\text { engineering associations, etc.) been identified? }\end{array}$ \\
\hline & $\begin{array}{l}1.2 \text { Educational } \\
\text { Objectives }\end{array}$ & $\begin{array}{l}\text { Are the programme educational objectives consistent with the mission of } \\
\text { the Higher Education Institution (HEI) and with the needs of the } \\
\text { interested parties (such as students, industry, engineering associations, } \\
\text { etc.)? }\end{array}$ \\
\hline & \multirow[t]{2}{*}{$\begin{array}{l}\text { 1.3 Programme } \\
\text { Outcomes }\end{array}$} & $\begin{array}{l}\text { Do the programme outcomes cover the programme outcomes, for } \\
\text { accreditation (cf. Section 1)? }\end{array}$ \\
\hline & & $\begin{array}{l}\text { Are the programme outcomes consistent with the programme } \\
\text { educational objectives? }\end{array}$ \\
\hline \multirow[t]{4}{*}{$\begin{array}{l}\text { 2. Educational } \\
\text { Process }\end{array}$} & 2.1 Planning & $\begin{array}{l}\text { Does the curriculum ensure the achievement of the programme } \\
\text { outcomes? }\end{array}$ \\
\hline & \multirow[t]{2}{*}{2.2 Delivery } & Is teaching delivered according to planning? \\
\hline & & $\begin{array}{l}\text { Are counselling and support-workload offered to the students adequate } \\
\text { to promote the achievement of the modules' specific learning outcomes? }\end{array}$ \\
\hline & $\begin{array}{l}2.3 \text { Learning } \\
\text { Assessment }\end{array}$ & $\begin{array}{l}\text { Have examinations, projects and other assessment methods, been } \\
\text { designed to evaluate the extent to which students can demonstrate } \\
\text { achievement of the learning outcomes of single modules and } \\
\text { programme outcomes respectively throughout the programme and at its } \\
\text { conclusion? }\end{array}$ \\
\hline \multirow[t]{8}{*}{$\begin{array}{l}\text { 3. Resources and } \\
\text { Partnerships }\end{array}$} & \multirow[t]{2}{*}{$\begin{array}{l}\text { 3.1 Academic and } \\
\text { Support Staff }\end{array}$} & $\begin{array}{l}\text { Is the academic staff adequate to accomplish the programme } \\
\text { outcomes? }\end{array}$ \\
\hline & & $\begin{array}{l}\text { Is the technical and administrative support staff adequate to accomplish } \\
\text { the programme outcomes? }\end{array}$ \\
\hline & \multirow[t]{4}{*}{ 3.2 Facilities } & Are the classrooms adequate to accomplish the programme outcomes? \\
\hline & & $\begin{array}{l}\text { Are the computing facilities adequate to accomplish the programme } \\
\text { outcomes? }\end{array}$ \\
\hline & & $\begin{array}{l}\text { Are the laboratories, workshops and associated equipment adequate to } \\
\text { accomplish the programme outcomes? }\end{array}$ \\
\hline & & $\begin{array}{l}\text { Are the libraries and associated equipment and services adequate to } \\
\text { accomplish programme outcomes? }\end{array}$ \\
\hline & 3.3 Financial Resources & $\begin{array}{l}\text { Are the financial resources adequate to accomplish the programme } \\
\text { outcomes? }\end{array}$ \\
\hline & 3.4 Partnerships & $\begin{array}{l}\text { Do the partnerships the } \mathrm{HEI} \text { and the programme are participating in } \\
\text { contribute to accomplish the programme outcomes and facilitate the } \\
\text { mobility of the students? }\end{array}$ \\
\hline \multirow[t]{4}{*}{$\begin{array}{l}\text { 4. Assessment of } \\
\text { Educational Process }\end{array}$} & \multirow[t]{2}{*}{4.1 Students } & $\begin{array}{l}\text { Do the students enrolled in the programme have the right } \\
\text { knowledge and attitudes to achieve the programme outcomes in the } \\
\text { expected time? }\end{array}$ \\
\hline & & $\begin{array}{l}\text { Do the results related to the students' career attest the achievement of } \\
\text { the programme outcomes in the expected time? }\end{array}$ \\
\hline & \multirow[t]{2}{*}{4.2 Graduates } & Do graduates enter an occupation corresponding to their qualification? \\
\hline & & $\begin{array}{l}\text { Do stakeholders (graduates, employers, etc.) confirm the } \\
\text { achievement of the programme's educational objectives? }\end{array}$ \\
\hline \multirow[t]{4}{*}{$\begin{array}{l}\text { 5. Management } \\
\text { System }\end{array}$} & $\begin{array}{l}5.1 \text { Organisation and } \\
\text { decision-making } \\
\text { processes }\end{array}$ & $\begin{array}{l}\text { Are HEl's and programme's organisation and decision-making processes } \\
\text { adequate to accomplish the programme outcomes? }\end{array}$ \\
\hline & \multirow[t]{3}{*}{$\begin{array}{l}5.2 \text { Quality Assurance } \\
\text { System }\end{array}$} & $\begin{array}{l}\text { Are HEl's and programme's Quality Assurance Systems effective to } \\
\text { ensure the achievement of the programme outcomes? }\end{array}$ \\
\hline & & $\begin{array}{l}\text { Are the delivery process', students' and graduates' results analysed and } \\
\text { used to promote continual improvement of the programme? }\end{array}$ \\
\hline & & $\begin{array}{l}\text { Are needs, objectives and outcomes, educational process, resources } \\
\text { and partnerships, management system periodically re-examined? }\end{array}$ \\
\hline
\end{tabular}




\section{EUR-ACE procedure for programme assessment and accreditation}

The first step of the EUR-ACE accreditation process is the preparation of a self-assessment report according to the requirements listed in the previous section.

The report is examined by an accreditation team in preparation for a site visit at the university. The site visit should include meetings with the university management, academic and support staff members, current and former students, and employers; visits to facilities (libraries, laboratories, etc.); and review of project work, final papers etc. At the end of the site visit, feedback from the accreditation team is presented.

The accreditation team then writes a report. The fulfilment of each individual requirement is assessed, using a scale with at least the following three levels: Acceptable; Acceptable with prescriptions; Unacceptable. The overall achievement of the requirements is also evaluated using a scale with at least three levels: Accredited without reservation; Accredited with prescriptions; Not accredited. The university has the opportunity to check the report for factual errors.

The final accreditation decision is taken by an accreditation institution, and may be valid for up to six years. After that time, re-accreditation is required.

\section{COMPARISON}

This section presents a comparison of the CDIO and EUR-ACE quality assurance system components. We start by contrasting the programme goals of each approach - the CDIO and EUR-ACE syllabi. We then discuss how the standards of CDIO related are to the accreditation requirements of EUR-ACE. Finally, we seek to identify advantages and disadvantages of a rating-based quality assurance approach like that of CDIO with a threshold-based one, such as EUR-ACE's.

\section{The CDIO syllabus vs. the EUR-ACE syllabus}

The relationships between the CDIO and EUR-ACE syllabi are mapped in Table 5. In this table, the $2^{\text {nd }}$ cycle version of the EUR-ACE syllabus is used as it includes a few additional outcomes as compared to the $1^{\text {st }}$ cycle one.

However, prior to scrutinizing the table, we note that the EUR-ACE standard lacks a "portal" statement of what engineers do, comparable to CDIO's "Engineers Conceive-DesignImplement-Operate complex systems in a modern, team-based environment". The EUR-ACE documentation states the term "engineer" has been avoided because of the confusion that could arise from its widely different interpretations within Europe, including specific regulatory meanings in some countries [7]. However, through the main headings of the EUR-ACE syllabus, we observe that the "EUR-ACE engineer" seems to be primarily focused on Analysis-Design-Investigation, essentially the Conceive and Design phases in CDIO. By contrast, a "CDIO engineer" should also be able to Implement and Operate, to be able work throughout the full product/system/process lifecycle.

These differences are also visible in Table 5, where all EUR-ACE items have CDIO correspondents, while the CDIO syllabus categories 4.5 (Implementing) and 4.6 (Operating) lack EUR-ACE counterparts. 
Table 5

EUR-ACE syllabus items vs. the CDIO syllabus.

\begin{tabular}{|c|c|c|c|c|c|c|c|c|c|c|c|c|c|c|c|c|c|}
\hline \multirow{2}{*}{$\begin{array}{l}\text { EUR-ACE } \\
\text { syllabus, } \\
\text { 2nd cycle }\end{array}$} & \multicolumn{17}{|c|}{ CDIO syllabus level $x . x$} \\
\hline & 1.1 & 1.2 & 1.3 & 2.1 & 2.2 & 2.3 & 2.4 & 2.5 & 3.1 & 3.2 & 3.3 & 4.1 & 4.2 & 4.3 & 4.4 & 4.5 & 4.6 \\
\hline 1.1 & $\bar{x}$ & & & & & & & & & & & & & & & & \\
\hline 1.2 & & $\bar{X}$ & & & & & & & & & & & & & & & \\
\hline 1.3 & & & $\mathbf{X}$ & & & & & & & & & & & & & & \\
\hline 1.4 & & & & & & $\mathbf{x}$ & & & & & & & & & $\bar{x}$ & & \\
\hline 2.1 & & & & $\bar{x}$ & & & & & & & & & & & & & \\
\hline 2.2 & & & & $x$ & & & & & & & & & & 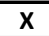 & $x$ & & \\
\hline 2.3 & & & & $\bar{x}$ & & & & & & & & & & $\bar{x}$ & $x$ & & \\
\hline 2.4 & & & $\mathbf{X}$ & $x$ & & & & & & & & & & 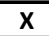 & $x$ & & \\
\hline 3.1 & & & & & & & & & & & & & & $\bar{x}$ & $\bar{x}$ & & \\
\hline 3.2 & & & & & & & $x$ & & & & & & & 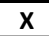 & $x$ & & \\
\hline 3.3 & & & & & & $x$ & & & & & & & & $x$ & $x$ & & \\
\hline 4.1 & & & & & $\bar{x}$ & & & & & & & & & & & & \\
\hline 4.2 & & & & & $\bar{x}$ & & & & & & & & & & & & \\
\hline 4.3 & & & & & $\bar{x}$ & & & & & & & & & & & & \\
\hline 4.4 & & & $\mathbf{X}$ & & $\bar{x}$ & & & & & & & & & & & & \\
\hline 5.1 & & $\mathbf{X}$ & $\mathbf{X}$ & $x$ & & & & & & & & & & & & & \\
\hline 5.2 & & $\mathbf{X}$ & $\mathbf{X}$ & $x$ & & $x$ & & & & & & & & & & & \\
\hline 5.3 & & 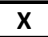 & $\mathbf{X}$ & $x$ & & & & & & & & & & & & & \\
\hline 5.4 & & & & & & & & & & & & $x$ & $x$ & & & & \\
\hline 6.1 & & & & & & & & & $x$ & & & & & & & & \\
\hline 6.2 & & & & & & & & & & $x$ & & & & & & & \\
\hline 6.3 & & & & & & & & $\bar{x}$ & & & & $x$ & & & & & \\
\hline 6.4 & & & & & & & & & & & & & $x$ & & & & \\
\hline 6.5 & & & & & & & $x$ & & & & & & & & & & \\
\hline 6.6 & & & & & & & & & $x$ & & & & & $x$ & & & \\
\hline
\end{tabular}

It should also be noted that there are significant differences between $1^{\text {st }}$ and $2^{\text {nd }}$ cycle goals in the EUR-ACE syllabus. If the analysis is limited to the $1^{\text {st }}$ cycle EUR-ACE requirements, more differences can be observed. For this cycle, the EUR-ACE syllabus also lacks correspondents to 2.3 (Systems thinking), 3.3 (Communication in foreign languages) and 4.3 (Conceiving).

A principal difference between the EUR-ACE and CDIO syllabi is that proficiency levels are "given" in the EUR-ACE syllabus, whilst they should be developed by a CDIO programme by surveying its stakeholders. Comparing proficiency levels is complicated by the one-to-many relationships between some syllabi items. Nevertheless, some comparisons can be made by translating EUR-ACE syllabi items to the MIT activity based proficiency scale [8] and comparing them with data from CDIO syllabus surveys. The MIT scale was developed for the first CDIO syllabus survey and provides a proficiency taxonomy with five levels (Table 6):

Table 6

MIT activity-based proficiency scale.

\begin{tabular}{|l|l|}
\hline 1 & To have experienced or been exposed to \\
\hline 2 & To be able to participate in and contribute to \\
\hline 3 & To be able to understand and explain \\
\hline 4 & To be skilled in the practice or implementation of \\
\hline 5 & To be able to lead or innovate in \\
\hline
\end{tabular}


Table 7

Comparisons of proficiency levels (PL) in EUR-ACE, in a Swedish CDIO syllabus survey, and in the Swedish degree ordinance.

\begin{tabular}{|c|c|c|c|c|c|c|}
\hline \multirow{2}{*}{$\begin{array}{l}\text { CDIO syllabus } \\
\text { item }\end{array}$} & \multicolumn{2}{|l|}{ EUR-ACE } & \multicolumn{2}{|c|}{ Swedish survey } & \multicolumn{2}{|l|}{ Swedish degree ordinance } \\
\hline & Text & $\mathrm{PL}$ & Text & $\mathrm{PL}$ & Text & PL \\
\hline $\begin{array}{c}2.5 \\
\begin{array}{c}\text { Professional } \\
\text { skills }\end{array}\end{array}$ & $\begin{array}{l}\text { Commit to professional ethics, } \\
\text { responsibilities and norms of } \\
\text { engineering practice }\end{array}$ & 2 & $\begin{array}{c}\text { Able to } \\
\text { participate/able } \\
\text { to explain }\end{array}$ & 2.6 & $\begin{array}{l}\text { Demonstrate aw areness of } \\
\text { ethical aspects of research } \\
\text { and development w ork }\end{array}$ & 1 \\
\hline Teamwork & $\begin{array}{l}\text { Function effectively as leader } \\
\text { of a team that may be } \\
\text { composed of different } \\
\text { disciplines and levels }\end{array}$ & 5 & $\begin{array}{l}\text { Skilled in the } \\
\text { practice of } \\
\text { teamw ork }\end{array}$ & 3.9 & $\begin{array}{l}\text { Engage in teamw ork and } \\
\text { cooperation in groups of } \\
\text { varying composition; }\end{array}$ & 4 \\
\hline Communication & $\begin{array}{l}\text { Work and communicate } \\
\text { effectively in national and } \\
\text { international contexts. }\end{array}$ & 4 & $\begin{array}{c}\text { Able to } \\
\text { understand/ } \\
\text { skilled in the } \\
\text { practice of } \\
\text { communication }\end{array}$ & 3.6 & $\begin{array}{l}\text { Clearly present and discuss } \\
\text { their conclusions ... orally and } \\
\text { in w riting, in national and } \\
\text { international contexts }\end{array}$ & 4 \\
\hline
\end{tabular}

We can then compare the proficiency levels for three EUR-ACE syllabus items which have single CDIO syllabus item correspondents, with data from a survey of Swedish industry leaders on their expectations on graduates [12]. The related statements from the Swedish degree ordinance for the MScEng degree are introduced as a benchmark [13]. See Table 7.

It is apparent from Table 7 that the stated proficiency levels vary. EUR-ACE states a significantly higher goal for team leadership capabilities (3.1 Teamwork). However, it can be questioned if it is a realistic goal for all recent graduates from a $2^{\text {nd }}$ cycle engineering programme to have this capability. For 3.2 Communication, the desired proficiency levels are reasonably similar. For 2.5 Professional skills, the spread is the largest.

The major differences between the EUR-ACE and CDIO syllabus are similar to those between the CDIO syllabus and the ABET criteria [8] and between the CDIO syllabus and the Swedish engineering [4]. However, the somewhat higher level of detail of the EUR-ACE syllabus as compare with the two other syllabi (25 items vs. 10 and 12 , respectively) results in a simpler mapping. There are more one-to-one or one-to-few relationships in the EURACE-CDIO table. This should facilitate the application of the EUR-ACE as a tool in educational development. However, the CDIO syllabus has 3-4 additional levels of detail, supporting programme-level as well as course-level educational development.

\section{The CDIO standards vs. the EUR-ACE requirements for accreditation}

Now let us consider the relationship between the CDIO standards and the EUR-ACE requirements for accreditation. The EUR-ACE accreditation standards/criteria are "Whats", ie they state what should be achieved but not how, it is up to the accredited university to devise solutions. The CDIO standards are "Hows".

Table 8 shows that CDIO standards address of 18 out of 24 EUR-ACE requirements. Criteria that lack corresponding CDIO standard include teacher and support staff availability, entrance requirements, organization, financial resources, throughput time and partnerships. On the next level, the EUR-ACE standards identify about 30 evidentiary items that should be part of the accreditation self-assessment package. About $2 / 3$ of these can be directly addressed through CDIO materials. However, the EUR-ACE accreditation criteria also require many specific documentary evidence which are not CDIO-specific, including 
Table 8

EUR-ACE accreditation criteria vs. CDIO standards

\begin{tabular}{|c|c|c|c|}
\hline $\begin{array}{l}\text { Guidelines for } \\
\text { Accreditation }\end{array}$ & Criteria to be assessed & Requirements & CDIO Std \\
\hline \multirow[t]{4}{*}{$\begin{array}{l}\text { 1. Needs, Objectives } \\
\text { and Outcomes }\end{array}$} & $\begin{array}{l}1.1 \text { Needs of the } \\
\text { Interested Parties }\end{array}$ & $\begin{array}{l}\text { Have the needs of the interested parties (such as students, industry, } \\
\text { engineering associations, etc.) been identified? }\end{array}$ & 1,2 \\
\hline & $\begin{array}{l}1.2 \text { Educational } \\
\text { Objectives }\end{array}$ & $\begin{array}{l}\text { Are the programme educational objectives consistent with the mission of } \\
\text { the Higher Education Institution (HEI) and with the needs of the } \\
\text { interested parties (such as students, industry, engineering associations, } \\
\text { etc.)? }\end{array}$ & 2 \\
\hline & \multirow[t]{2}{*}{$\begin{array}{l}\text { 1.3 Programme } \\
\text { Outcomes }\end{array}$} & $\begin{array}{l}\text { Do the programme outcomes cover the programme outcomes, for } \\
\text { accreditation (cf. Section 1)? }\end{array}$ & 2 \\
\hline & & $\begin{array}{l}\text { Are the programme outcomes consistent with the programme } \\
\text { educational objectives? }\end{array}$ & 2 \\
\hline \multirow[t]{4}{*}{$\begin{array}{l}\text { 2. Educational } \\
\text { Process }\end{array}$} & 2.1 Planning & $\begin{array}{l}\text { Does the curriculum ensure the achievement of the programme } \\
\text { outcomes? }\end{array}$ & 3 \\
\hline & \multirow[t]{2}{*}{2.2 Delivery } & Is teaching delivered according to planning? & 12 \\
\hline & & $\begin{array}{l}\text { Are counselling and support-workload offered to the students adequate } \\
\text { to promote the achievement of the modules' specific learning outcomes? }\end{array}$ & \\
\hline & $\begin{array}{l}2.3 \text { Learning } \\
\text { Assessment }\end{array}$ & $\begin{array}{l}\text { Have examinations, projects and other assessment methods, been } \\
\text { designed to evaluate the extent to which students can demonstrate } \\
\text { achievement of the learning outcomes of single modules and } \\
\text { programme outcomes respectively throughout the programme and at its } \\
\text { conclusion? }\end{array}$ & 11 \\
\hline \multirow[t]{8}{*}{$\begin{array}{l}\text { 3. Resources and } \\
\text { Partnerships }\end{array}$} & \multirow[t]{2}{*}{$\begin{array}{l}\text { 3.1 Academic and } \\
\text { Support Staff }\end{array}$} & $\begin{array}{l}\text { Is the academic staff adequate to accomplish the programme } \\
\text { outcomes? }\end{array}$ & 9,10 \\
\hline & & $\begin{array}{l}\text { Is the technical and administrative support staff adequate to accomplish } \\
\text { the programme outcomes? }\end{array}$ & 9,10 \\
\hline & \multirow[t]{4}{*}{ 3.2 Facilities } & Are the classrooms adequate to accomplish the programme outcomes? & 6 \\
\hline & & $\begin{array}{l}\text { Are the computing facilities adequate to accomplish the programme } \\
\text { outcomes? }\end{array}$ & 6 \\
\hline & & $\begin{array}{l}\text { Are the laboratories, workshops and associated equipment adequate to } \\
\text { accomplish the programme outcomes? }\end{array}$ & 6 \\
\hline & & $\begin{array}{l}\text { Are the libraries and associated equipment and services adequate to } \\
\text { accomplish programme outcomes? }\end{array}$ & 6 \\
\hline & 3.3 Financial Resources & $\begin{array}{l}\text { Are the financial resources adequate to accomplish the programme } \\
\text { outcomes? }\end{array}$ & \\
\hline & 3.4 Partnerships & $\begin{array}{l}\text { Do the partnerships the } \mathrm{HEI} \text { and the programme are participating in } \\
\text { contribute to accomplish the programme outcomes and facilitate the } \\
\text { mobility of the students? }\end{array}$ & \\
\hline \multirow[t]{4}{*}{$\begin{array}{l}\text { 4. Assessment of } \\
\text { Educational Process }\end{array}$} & \multirow[t]{2}{*}{4.1 Students } & $\begin{array}{l}\text { Do the students enrolled in the programme have the right } \\
\text { knowledge and attitudes to achieve the programme outcomes in the } \\
\text { expected time? }\end{array}$ & \\
\hline & & $\begin{array}{l}\text { Do the results related to the students' career attest the achievement of } \\
\text { the programme outcomes in the expected time? }\end{array}$ & \\
\hline & \multirow[t]{2}{*}{4.2 Graduates } & Do graduates enter an occupation corresponding to their qualification? & 12 \\
\hline & & $\begin{array}{l}\text { Do stakeholders (graduates, employers, etc.) confirm the } \\
\text { achievement of the programme's educational objectives? }\end{array}$ & 12 \\
\hline \multirow[t]{4}{*}{$\begin{array}{l}\text { 5. Management } \\
\text { System }\end{array}$} & $\begin{array}{l}\text { 5.1 Organisation and } \\
\text { decision-making } \\
\text { processes }\end{array}$ & $\begin{array}{l}\text { Are HEl's and programme's organisation and decision-making processes } \\
\text { adequate to accomplish the programme outcomes? }\end{array}$ & \\
\hline & \multirow[t]{3}{*}{$\begin{array}{l}5.2 \text { Quality Assurance } \\
\text { System }\end{array}$} & $\begin{array}{l}\text { Are HEl's and programme's Quality Assurance Systems effective to } \\
\text { ensure the achievement of the programme outcomes? }\end{array}$ & 12 \\
\hline & & $\begin{array}{l}\text { Are the delivery process', students' and graduates' results analysed and } \\
\text { used to promote continual improvement of the programme? }\end{array}$ & 12 \\
\hline & & $\begin{array}{l}\text { Are needs, objectives and outcomes, educational process, resources } \\
\text { and partnerships, management system periodically re-examined? }\end{array}$ & 12 \\
\hline
\end{tabular}


examples of final projects, examination papers, budget, research merits and so on. Preparing for a EUR-ACE accreditation is a comprehensive activity. However, a programme that carries out a CDIO introduction will have worked through a majority of the issues raised in the accreditation process.

Some CDIO standards do not appear in Table 8; this applies to CDIO standards 4, 5, 7 and 8. These standards refer to CDIO-specific curricular elements (introductory courses, designimplement-experiences) and pedagogical approaches (integrated and active learning). These elements are essential for the quality of a CDIO programme. However, it is not evident how these elements will be valued in a EUR-ACE accreditation.

\section{The CDIO self-evaluation model vs. the EUR-ACE accreditation process}

Finally, let us consider the two models from a quality assurance process perspective. The key differences between the models are summarized in Table 9.

A CDIO self-evaluation is typically performed internally. However, the external view of an accrediting team may be more critical and provide more reference to educational practices at other universities. The external and compulsory nature of an accreditation may also give a stronger sense of urgency for change needs identified in the self-assessment step or pointed out by the accreditation team: Someone from the outside is requiring us to make these changes. An internal, voluntary evaluation such as a CDIO self-evaluation based one may also be slower in accommodating emerging external goals.

An evaluation towards a rating scale, such as the CDIO self-evaluation model, is more suitable for continuous improvement: It is a recurring activity, and it provides for target-setting and follow-up of multi-year improvement projects, whereas a threshold-based evaluation such as a EUR-ACE accreditation does not provide the university with any direction for future development, beyond fulfilling the requirements. A CDIO self-evaluation, with its more limited information requirements, is possible to update annually, whilst an accreditation typically takes place with six-year internals. The CDIO self-evaluation model also supports follow-up of "How" educational elements (introductory course, integrated learning etc) which are not considered in the EUR-ACE requirements, which are stated in "What" terms, and refrains from prescribing specific curricular elements (except for "projects") and pedagogical approaches.

A possible future development direction for the EUR-ACE standards is to incorporate some rating-scale elements, enabling systematic comparisons between different engineering programmes, and guiding continuous improvement beyond the threshold value. The feasibility of inclusion of such components has been demonstrated by the Swedish national agency for higher education [2]. If the trend towards ranking-oriented evaluations continues, a CDIO standards-based self evaluation can be an important part of the evaluation package. The EUR-ACE standards could also refine the requirement for a quality assurance system, to state that a system with a proven support for continuous improvement is required.

One possible future development of the CDIO self-evaluation model includes encouraging a stronger external element in the evaluation, perhaps by inviting external evaluators, or by conducting bilateral university evaluations. An external view could bring in new perspectives and contribute to raise the quality and completeness of the (self-) evaluation data. Another development is to encourage universities to customize the CDIO self-evaluation model, for instance by including measurements and goals for student retention in the same follow-up. 
Table 9

Comparison between CDIO self-evaluation process and EUR-ACE accreditation process

\begin{tabular}{|l|l|}
\hline CDIO self-evaluation & EUR-ACE accreditation \\
\hline Internal evaluators & External accreditation team \\
\hline Internal goals & External goals \\
\hline Voluntary & Compulsory \\
\hline Evaluation with respect to rating scale & Threshold \\
\hline Yearly & Six-year intervals \\
\hline Limited amount of data & Comprehensive amount of data \\
\hline
\end{tabular}

\section{CONCLUSIONS}

The paper compares the elements of a CDIO quality assurance system with those of EURACE. We conclude that:

- The CDIO syllabus reflects a more encompassing view of engineering than EUR-ACE's, by considering the full product/system/process lifecycle, including the implementing and operating life phases. The proficiency levels of the CDIO and EUR-ACE are, however, difficult to compare.

- The EUR-ACE accreditation requirements are extensive and include elements not addressed in the CDIO framework, eg concerning financial resources and decisionmaking. The CDIO standards provide "solutions" on how to work with about $3 / 4$ of the issues raised in a EUR-ACE accreditation.

- Four of the CDIO standards (4, 5, 7, and 8) define educational elements which are not explicitly discussed in EUR-ACE accreditation requirements.

- An evaluation process based on a rating scale, such as the CDIO self-evaluation model, is more useful for guiding a continuous improvement process than a threshold value scale, such as used in a EUR-ACE accreditation.

\section{REFERENCES}

[1] Accreditation Board of Engineering and Technology, Criteria for Accrediting Engineering Programs: Effective for Evaluations during the 2000-2001 Accreditation Cycle, 2000. Available at http://www.abet.org.

[2] Högskoleverket, Utvärdering av utbildningar till civilingenjör vid svenska universitet och högskolor - fulltextversion (Evaluation of "Civilingenjör" Degree Programs at Swedish Universities), Rapport 2006:8 R, Högskoleverket, Stockholm, Sweden, 2006.

[3] Crawley, E. F., Malmqvist, J., Brodeur, D. R, Östlund, S. Rethinking Engineering Education The CDIO Approach, Springer-Verlag, New York, 2007.

[4] Malmqvist, J., Relation between the Dublin Descriptors and Program Goal Statements based on the CDIO Syllabus, Technical Report, Chalmers University of Technology, Göteborg, 2006.

[5] Malmqvist, J., Edström, K., Gunnarsson, S. Östlund, S., "The Application of CDIO Standards in the Evaluation of Swedish Engineering Degree Programmes", World Transactions of Engineering and Technology, Vol. 5, No. 2, pp. 361-364, 2006.

[6] Malmqvist, J., Sadurskis, A., "Quality Assurance of Engineering Education in Sweden", Book chapter forthcoming in Engineering Education Quality Assurance - A Global Perspective, Patil, A. S., Gray, P. (Eds.), Springer-Verlag, 2009. 
[7] ENAEE (European Network for Accreditation of Engineering Education), EUR-ACE Framework Standards for the Accreditation of Engineering Programmes, http://www.enaee.eu/pdf/EURACE_Framework_Standards_20110209.pdf, 2008, accessed on May 4, 2009.

[8] Crawley, E., The CDIO Syllabus - A Statement of Goals for Undergraduate Engineering Education, Department of Aeronautics and Astronautics, Massachusetts Institute of Technology, 2001. Available at http://www.cdio.org.

[9] Enelund, M, Bankel, J., The Mechanical Engineering Programme at Chalmers University of Technology - Application for appointment as Centre of Excellent Quality in Higher Education, Chalmers University of Technology, Göteborg, Sweden, 2008.

[10] European Commission: DG Education and Culture, The European Qualification Framework for Lifelong Learning (EQF), Office for Official Publications of the European Communities, Luxemburg, 2008.

[11] ENQA (European Association for Quality Assurance in Higher Education), Standards and Guidelines for Quality Assurance in the European Higher Education Area, $2^{\text {nd }}$ Ed., 2007, Helsinki, Finland. Available at http://www.enqa.eu/pubs.lasso.

[12] Bankel, J., Berggren, K.-F., Blom, K., Crawley, E., Wiklund, I., Östlund, S., "The CDIO Syllabus - A Comparative Study of Expected Student Proficiency", European Journal of Engineering Education, Vol. 28, No. 3, pp 297-315, 2003.

[13] Ministry of Education and Research. Higher Education Ordinance, SFS 1993:100, with amendments up to SFS 2006:1054, Stockholm, Sweden, 2006.

\section{Biographical Information}

Dr Johan Malmqvist is a professor in Product Development and Dean of Education at Chalmers University of Technology, Göteborg, Sweden. His current research focuses on information management in the product development process (PLM) and on curriculum development methodology.

\section{Corresponding author}

Professor Johan Malmqvist

Chalmers University of Technology

Department of Product and Production Development

SE-412 96 Göteborg, SWEDEN

Phone: $\quad$ +46317721382

E-mail: johan.malmqvist@chalmers.se 